УДК $327: 94$ (469) «18/19»

DOI: https://doi.org/10.33782/eminak2019.3(27).324

\title{
ВПЛИВ МІЖНАРОДНИХ ВІДНОСИН НА РОЗВИТОК І КРАХ ОСТАННЬОЇ КОЛОНІАЛЬНОЇ ІМПЕРІЇ В ЄВРОПІ
}

\author{
Микола Олійник \\ Хмельницький національний університет (Хмельницький, Україна) \\ e-mail: mpoliynyk@ukr.net \\ ORCID: https://orcid.org/0000-0002-3440-4965
}

У статті проаналізовано особливості Нової держави, акцентовано увагу на їі пристосуванні до зміни міжнародного становища. Розглянуто вплив членства у НАТО на розвиток Португалії. Досліджено обставини військового перевороту та його переростання у демократичну революцію. Наголошено на міжнародному значенні «Революції гвоздик».

Ключові слова: салазаризм, збройні сили, «Революція гвоздик», деколонізація, демократія

Зникнення з карти світу у 1991 р. євразійської «імперії зла» - Радянського Союзу - практично завершило колоніальну епоху в історії людства. Прагнення Росії відновити імперію роблять актуальним аналіз обставин розпаду не лише їі євразійських, а й європейських колоніальних попередниць. Першою втратила колонії переможена у Першій світовій війні Німеччина. Крах британської, бельгійської, голландської, іспанської та французької імперій став наслідком низки факторів, зумовлених, насамперед, Другою світовою війною та національно-визвольною боротьбою корінних народів колоній. Проте найслабша серед них - португальська - змогла протриматись аж до 1975 р.

Відтак цілком природним $є$ науковий інтерес дослідників до вивчення феномену такої живучості. У загальному вигляді дану проблему та ії місце в історії Португалії розглянув Ж. Сорайва1. Окремі аспекти боротьби Португалії з Великобританією та Німеччиною за збереження і розширення колоніальних володінь у кінці XIXст. знайшли відображення у статтях Л. Питльованої ${ }^{2}$ та С. Трояна ${ }^{3}$ Роль католицької церкви у португальському суспільстві та державі на різних етапах їхнього розвитку в XX ст. проаналізувала Н. Поташинська4 ${ }^{4}$ Становленню, розвитку та падінню «Нової держави» присвячені статті І. Полонського 5 й Ю. Рейхеля6. Перетворення географічного поняття «лузотропікалізм» в ідеологічну підвалину режиму А. Салазара про-

\footnotetext{
1 Сорайва Ж.Э. История Португалии. Москва: «Весь мир», 2007. 372 с.

2 Питльована Л.Ю. Англо-німецькі суперечності на африканському континенті на зламі XIX-XX ст. та їх роль у наростанні кризи системи міжнародних відносин напередодні першої світової війни // Народи світу і Велика війна 1914-1918 рр. Матеріали Всеукраїнської наукової конференції 34 квітня 2015 р. Вінниця: ТОВ «Нілан-ЛТД», 2015. С. 19-25.

3 Троян С.С. Колоніальна політика кайзерівської Німеччини у форматі боротьби за «місце під сонцем» (1896-1900 роки) // Історична пам’ять (Полтава). 2011. № 1. С. 94-109.

4 Поташинская Н.Н. Церковь Португалии и «революция гвоздик» // Берегиня 777. Сова. 2014. № 1. C. 153-157. URL: http://www.isras.ru/files/ File/publ/Potashinskaya_Bereginya_2014_pdf

5 Полонский И. «Новое государство» профессора Салазара. // Военное обозрение. 2015. 17 августа. URL: https://topwar.ru/80608-novoe-gosudarstvo-professora-salazara.html

6 Райхель Ю. Професор-диктатор. Правління Салазара тривало 40 років // День. 2010. 17 серпня. URL: https://day.kyiv.ua/uk/article/svitovi-diskusiyi/profesor-diktator
} 
аналізували М.В. де Альмейда7 та Х. Пімента, Х. Сарменто, А. де Азеведо ${ }^{8}$ Роль збройних сил в історії Португалії, вплив членства в НАТО на розвиток опозиційного руху, фактори, які зумовили провідне місце офіцерів у «Революції гвоздик», дослідили 0. Осуна й Х. Хав'єр ${ }^{9}$, Р. Валера ${ }^{10}$, К. Куширець ${ }^{11}$ та інші. Різним аспектам «Революції гвоздик» - від причин військового перевороту до його переростання у демократичну революцію - присвячені роботи К. Астафьєвої 12 , Г. Гомеша 13 , Г. Кузнєцова ${ }^{14}$, Е.М. Ейртона 15 й ін. Питання функціонування органів місцевого самоврядування у часи салазаризму та після 1974 р. дослідила М.А. Пірес де Альмейда ${ }^{16}$. Аналіз проблеми диктатури у португальській історіографії постреволюційного періоду здійснив М. Лофф17. Однак вплив міжнародних відносин на її розвиток і крах досі залишається малодослідженим.

Метою даної статті $\epsilon$ науковий аналіз впливу міжнародних відносин на розвиток і крах португальської колоніальної імперії, що дозволяє з'ясувати, завдяки чому вона змогла пережити значно потужніші європейські імперії, але зазнала краху внаслідок безкровного військового перевороту, який переріс у демократичну «Революцію гвоздик».

У кінці XIX ст., коли розгорнулася завершальна стадія формування колоніальних імперій і починалася боротьба за переділ колоніальних володінь, мало хто вірив, що Португалія, яка перебувала на грані економічного краху, не тільки втримає свої колонії, а й збереже їх до середини 1970-х років. Адже після ультиматуму, висунутого Великою Британією 11 січня 1890 р., вона змушена була відмовитися від планів об'єднати сухопутним коридором свої колонії Анголу та Мозамбік, що було розцінено опозицією як акт національної зради 18.

Крім того, Німеччина, у рамках своєї «світової політики», прагнула з'єднати свої колонії Камерун і Південно-Східну Африку сухопутним коридором, захопивши при цьому Анголу та французькі й бельгійські володіння у долині річки Заїр. Наголоси-

\footnotetext{
7 Vale de Almeida M. Portugal's Colonial Complex: From Colonial Lusotropicalism to Postcolonial Lusophony. 2008. URL: http://miguelvaledealmeida. net/wp-content/uploads/2008/05/portugals-colonialcomplex.pdf.

8 Pimenta J.R., Sarmento J., Azevedo A.F. Lusotropicalism: Tropical geography under dictatorship, 19261974 // Singapore Journal of Tropical Geography. 2011. № 32 (2). P. 220-235.

${ }^{9}$ Osuna O., Javier J. The deep roots of the Carnation Revolution: 150 years of military interventionism in Portugal // Portuguese Journal of Social Science. 2014. № 13 (2). P. 215-231.

10 Varela R. «One, two, three MFA»: the rise and fall of Portugal\&apos;s Armed Forces Movement (MFA) // Revista Brasileira de História. 2012. Vol. 32, № 63. P. 407-430.

11 Куширець К.О. Підготовка «Рухом капітанів» революції гвоздик //Гілея: науковий вісник. Збір. наук. праць. 2017. Вип. 125 (10). С. 116-119.

12 Астафьева Е. Революция гвоздик. URL: https://diletant.media/articles/34661719/

13 Гомеш Г. Апрельская революция 1974 г. и демократические преобразования в Португалии (1974-1976 гг.). Автореф. дис.... канд. ист. наук. Москва, 2004. 24 с.

${ }_{14}^{14}$ Кузнецов Г. Конец великой империи: как «революция гвоздик» разрушила Большую Португалию. URL: https://um.plus/2016/04/26/konec-velikoj-imperii-kak-revoljucija-gvozdik-razrushilabolshuju-portugaliju/

${ }^{15}$ Aitor Hernández-Morales. Vasco Lourenço: «España le debe la democracia a la Revolución de los Claveles» // El mundo. 2018. 25 Abr.

16 Pires de Almeida, M.A. The revolution in local government: mayors in Portugal before and after 1974 // Continuity and Change. 2017. № 32 (2). P. 253-282.

17 Loff M. Dictatorship and revolution: Socio-political reconstructions of collective memory in postauthoritarian Portugal. // Culture and History Digital Journal. 2014. Vol.3, No. 2. URL: http://cultureandhistory.revistas.csic.es/index.php/cultureandhistory/article/view/56/213

18 Сорайва Ж.Э. Указ. раб С. 98.
} 
мо, що обидві імперії, керуючись власними геополітичними розрахунками та прагнучи використати іншу сторону для зміцнення своїх позицій, пішли на компроміс і 30 серпня 1898 р. підписали дві конвенції, які передбачали поділ португальської колоніальної імперії. До того ж Велика Британія отримала гарантії невтручання Німеччини у випадку ії̈ війни з бурами, а Лондон передав у німецьке володіння острови Самоа у Полінезії. Зауважимо, що поки у Берліні тішилися «великою дипломатичною перемогою», англійський уряд, керуючись стратегічними міркуваннями, 14 жовтня 1899 р. уклав з Португалією секретний Віндзорський протокол, яким гарантував недоторканість їі колоніальних володінь ${ }^{19}$. Цей протокол фактично перетворював Португалію у британську маріонетку.

У самій Португалії, користуючись ліберальною політикою королівської влади, республіканська опозиція використала зазначену угоду для ї̈ дискретизації й нагнітання революційних настроїв. Вона організувала низку виступів в армії та на флоті. Щоб спинити наростання анархії, король Карлуш I у травні 1907 р. надав прем'єрміністрові Жуану Франку Каштелу Бранку необмежені повноваження та розпустив парламент. Концентрація виконавчої влади у руках прем'єра дозволила йому безперешкодно проводити реформи. Це викликало опір республіканців, які боялися, що у разі успіху реформ втратять підтримку мас. Опозиція почала готувати змову. Але 28 січня 1908 р. змовників під проводом Жозе ді Алпоіна арештували. Проте вже 1 лютого 1908 р. змовники вбили Карлуша I та принца Луіша Філіпа. Змову не розкрили. Новий король Мануель II не зміг опанувати ситуацію і був усунутий від влади внаслідок демократичної революції 5 жовтня 1910 р.20

Революціонери проголосили республіку. Тимчасовий уряд очолив знаний письменник та історик Теофілу Брага. Було ухвалено низку прогресивних законів, зокрема про відокремлення церкви від держави, скасування дворянських звань... Однак реформи не змогли покращити міжнародного становища Португалії. Навпаки - були розірвані дипломатичні відносини з Ватиканом, поширювалися чутки, що у 1913 р. Англія та Німеччина майже домовилися про підписання нової угоди щодо поділу португальських колоній. Здавалося, що крах дряблої імперії неминучий. Проте вступ у Першу світову війну на боці Антанти дозволив не лише відновити дипломатичні відносини з Ватиканом, а й за підсумками війни продовжити своє існування 21.

Не змогли республіканці й підвищити життєвий рівень громадян. Повалити монархію виявилося простіше, ніж досягати компромісу з учорашніми соратниками, а тепер політичними опонентами, налагодити ефективне управління країною, не піддатися спокусі корупції, не зловживати владою. Це негативно позначилося на внутрішньому становищі країни. Як наслідок - упродовж 16 років існування Першої республіки змінилося дев'ять президентів, 44 прем'єр-міністри та три диктатори, сталося 25 збройних повстань, заколотів і спроб державного перевороту. Особливо ускладнилося становище після закінчення Першої світової війни. Так, національна валюта ескудо з 1919 р. до 1924 р. знецінилася майже у 17 разів ${ }^{22}$.

Паралельно зі стрімким наближенням економіки до колапсу в суспільстві, як і в багатьох країнах Європи, поширювалися праворадикальні ідеї. Преса привчала сус-

\footnotetext{
19 Питльована Л.Ю. Вказ. пр. С. 21-25; Троян С.С. Вказ. пр. С. 99-100; Полонский И. Указ. раб.

20 Сорайва Ж.Э. Указ. раб. С. 98.

21 Поташинская Н.Н. Указ. раб. С. 154-155; Райхель Ю. Указ. раб.

22 Сорайва Ж.Э. Указ. раб. С. 100; Райхель Ю. Указ. раб.; Полонский И. Указ. раб.
} 
пільство до думки, що «лише диктатура може нас врятувати»²3. Роль рятувальника взяли на себе військові. 28 травня 1926 р. генерал М. Гомеш да Кошта здійснив безкровний військовий переворот. А вже через два місяці відбувся ще один переворот. Диктатором став генерал А. Кармона24.

Однак, як і республіканці, військові не змогли нічого вдіяти. Криза лише поглиблювалася. Для порятунку економіки країни від краху запросили популярного у країні вченого-економіста, професора Коїмбрського університету (одного з найстаріших у світі) Антоніу де Олівейра Салазара. Ставши у 1928 р. міністром фінансів з надзвичайними повноваженнями, він упродовж року зумів збалансувати бюджет і стабілізувати ескудо. У 1932 р. він став головою Ради міністрів, а 1933 р. забезпечив ухвалення на референдумі Конституції «Нової держави». Вона базувалася на запозиченій в італійських фашистів ідеології корпоративізму та була оголошена «першою корпоративною конституцією в світі». Основний закон передбачав встановлення централізованого авторитарного режиму, який дозволив Салазару за два десятиліття інтегрувати еліти країни у такі нові корпоративні установи, як місцеві асоціації фермерів «gremios», котрі у поєднанні з підтримкою Католицької церкви, соціальними репресіями та потужною секретною службою контролювали кожен сегмент життя країни та регіонів.

Основними рисами «Нової держави» були страх, насильство, залякування та нагляд як основи політичного панування та забезпечення авторитаризму. Під контроль центральної влади було взято систему місцевого самоврядування. Вигоду від державного захисту отримали військовослужбовці, промисловці, землевласники та банкіри ${ }^{25}$.

Ідеологічною основою салазаризму був антикомунізм, який базувався на християнських цінностях. Фактично це був авторитарний консервативний режим, а не фашистський, як твердила радянська історіографія та її сучасні послідовники й автори лівих поглядів в інших країнах. Насправді Салазар не підтримував ні італійський фашизм, ні німецький націонал-соціалізм. Разом з тим Португалія підтримала Франко під час громадянської війни в Іспанії. Зокрема, німецькі й італійські кораблі з військовими вантажами для фалангістів отримали доступ до португальських портів. Крім того, кілька тисяч добровольців брали участь безпосередньо у боях на боці Франко. Як для пострадянської людини - це була дивна диктатура - без смертної кари та масових репресій ${ }^{26}$. Зауважимо, що оскільки режим забезпечив поступальний розвиток країни та покращення життєвого рівня, то більшість громадян підтримувала його. Обережна зовнішня політика, орієнтована на Великобританію, забезпечила зручне міжнародне становище Португалії у міжвоєнний період.

Особливе значення у міжвоєнний період португальський уряд надавав активній колоніальній пропаганді з метою обгрунтувати тезу, що «Португалія - не маленька країна!» та «оригінальність» португальської колоніальної експансії. Задля цього Школа колоніального управління, Географічне товариство Лісабона тощо здійснювали активну пропагандистську роботу. В ній використовувалися всі доступні засоби: португальський колоніальний атлас 1903 р. Франциско Теллеса, кінематограф

${ }^{23}$ Сорайва Ж.Э. Указ. раб. С. 100.

24 Райхель Ю. Указ. раб.; Полонский И. Указ. раб.

25 Поташинская Н.Н. Указ. раб. С. 156; Vale de Almeida M. Op. cit. Р. 254.

26 «Революция гвоздик»: как Португалия спасла себя от коммунизма. URL: https://antisovetsky.livejournal.com/14255.html; Райхель Ю. Указ. раб. 
(особливо популярним був фільм «0 Feitiço do Império» («Заклинання імперії»), 1940 р.), першу португальську колоніальну виставку в Порто у 1934 р. та Всесвітню виставку в Лісабоні у 1940 р. Цій же меті було підпорядковано велику реконструкцію Лісабонської набережної у 1940 р. При цьому наголошувалося, що вона проводиться в «мирному» Лісабоні, тоді як решта Європи переживала смертельну війну27.

Теоретичною основою «особливого статусу» португальської колоніальної імперії стало вчення «лузотропікалізму» бразильського етнографа Жілберто Фрейре, який вважав, що започаткована у XV ст. португальська імперія, завдяки субтропічному розташуванню Португалії, переплетінню багатьох культур впродовж її історії змогла досягти «асиміляції» своїх володінь у тропіках. Асиміляція грунтувалася на трьох стовпах: змішуванні етносів і рас, культурному злитті та відсутності расових забобонів. Як приклад успішності такої політики наводилася Бразилія 28.

Позитивним для Португалії стало дотримання нейтралітету під час Другої світової війни. Така політика зумовлювалася проанглійськими поглядами військового командування, які, проте, вважали португальські військові та матеріальні можливості явно недостатніми для того, щоб брати активну участь у війні. Це дозволило як надавати бази для флоту країн-членів антигітлерівської коаліції на Азорських островах і торгувати з ними стратегічною сировиною, насамперед, вольфрамом, так і одночасно поставляти його Німеччині, отримавши від неї за це через Швейцарію майже 40 тонн золота. Така гнучка політика дозволила вперше з кінця XVIII ст. отримати позитивне сальдо зовнішньої торгівлі ${ }^{29}$.

Співпраця з переможцями забезпечила збереження Португалією після завершення Другої світової війни своїх колоній. Розгортання ж «холодної війни» різко підвищило стратегічне значення португальських портів, особливо на Азорських островах, для військово-морських сил Заходу. Відтак Португалії запропонували стати членомзасновником НАТО у 1949 р. При цьому ніхто з союзників не звертав увагу на зростання у країні корупції та зловживання владою 30.

Членство в Альянсі забезпечило модернізацію оборонних структур Португалії й адаптацію її збройних сил до стандартів НАТО. Союзники, особливо США, постачали зброю та сприяли розвитку португальської оборонної промисловості. Новим для Португалії було впровадження, на вимогу союзників, елементів цивільного контролю за збройними силами та військово-промисловим комплексом. Багато офіцерів навчалися американським військовим персоналом, частина з них у військових академіях у США й інших країнах-членах НАТО. На основі рекомендацій НАТО було перебудовано систему військової освіти. Зокрема, у 1958 р. скасували плату за навчання у Військовій академії та встановили стипендії курсантам, що відкрило шлях до військової кар'єри вихідцям з нижчих і середніх прошарків суспільства. Ці офіцери, відомі як «покоління НАТО», здобули міжнародний досвід, багато хто з них став прихильником демократії. Вони незабаром зайняли керівні посади. Багато з них критикували режим і брали участь в опозиційних рухах і змовах з кінця 1950-х років ${ }^{31}$. 3окрема, колишній військовий аташе у США генерал Умберто Дельгадо, лідер опозиції, балотувався на пост президента у 1958 р., а відтак змушений був емігрувати до Іспа-

\footnotetext{
27 Pimenta, J.R., Sarmento, J. \& Azevedo A.F. Op. cit. P. 221-222.

28 Ibid. P. 226; Vale de Almeida M. Op. cit. P. 5-6; Osuna O., Javier J. Op. cit. P. 221.

29 Райхель Ю. Указ. раб.; Сорайва Ж. Э. Указ. раб. С. 101-102.

30 Osuna O., Javier J. Op. cit. P. 221.

31 Ibid. P. 221-222.
} 
нії, де його вистежили та вбили агенти політичної поліції Міжнародної поліції захисту держави (Polícia Internacional e de Defesa do Estado, PIDE)32. Зазначимо, що Адміністрація США, яку підтримав уряд Великобританії, засудила це вбивство й у квітні 1961 р. підтримала заколот під проводом генерала Ботелью Моніжа проти режиму А. Салазара ${ }^{33}$.

Реакція Лісабону була прогнозована - він скоротив співпрацю з Вашингтоном і НАТО. Це ускладнило міжнародне становище Португальської імперії, яке різко погіршилося з кінця 1961 р., коли Генеральна Асамблея ООН з ініціативи СРСР 14 грудня прийняла «Декларацію про надання незалежності колоніальним країнам і народам». Португальський уряд побачив у ній прагнення великих держав до перерозподілу на свою користь зон впливу та джерел сировини африканських і азійських країн. Спираючись на теорію лузотропікалізму, він наполягав, що території за межами Європи з 1951 р., відповідно до конституційної поправки, є не колоніями, а заокеанськими провінціями, тобто складовими частинами єдиної національної держави та національної території, а тому вони невідчужувані. Втрата ж заморських володінь означатиме для Португалії втрату незалежності, оскільки зникне критична маса, необхідна для забезпечення політичної самостійності Португальської держави. Проте така точка зору не сприймалася міжнародною спільнотою. Вона наполягала на тезі, що португальські «заморські провінції» $є$ справжніми колоніями ${ }^{34}$.

Втрата підтримки з боку США та Великобританії далася взнаки вже у грудні 1961 р., коли індійські війська, за моральної підтримки міжнародної спільноти та невтручання НАТО, за кілька днів відвоювали у Португаліїії колонії Гоа, Даман і Діу35.

Особливо погіршилося міжнародне становище Португалії після початку в 1961 p. колоніальної війни в Анголі, а згодом у Мозамбіку та Гвінеї-Бісау. Вона стала реакцією режиму Салазара на розгортання партизанської боротьби під проводом Народного руху за визволення Анголи (порт. Movimento Popular de Libertação de Angola) (МПЛА), Африканської партії незалежності Гвінеї та Кабо-Верде (порт. Partido Africano da Independência da Guiné e Cabo Verde) (ПАІГК) та Фронту визволення Мозамбіку (порт. Frente de Libertação de Moçambique) (ФРЕЛІМО), які отримували військову, організаційну, ідеологічну, кадрову та політичну підтримку від СРСР.

Щоб втримати колонії силою, довелося збільшити чисельність збройних сил Португалії з 40 тис. чоловік у 1961 р. до 217 тис. у 1974 р. Війна забирала до 40\% держбюджету. Зусилля уряду з розвитку інфраструктури у заморських територіях бажаного ефекту не давали. До того ж у 1964 р. під тиском Радянського Союзу Генеральна Асамблея ООН прийняла резолюцію про надання народам португальських колоній «моральної та матеріальної підтримки, необхідної для відновлення їхніх невід’ємних прав», i про санкції проти Португалії у вигляді розриву з нею дипломатичних відносин, закриття портів та аеродромів для її кораблів і літаків, припинення торгівлі 36 . Невдовзі союзники СРСР і майже всі держави Азії й Африки бойкотували португальський режим. Навіть їі союзники по НАТО всіляко підкреслювали невдоволення небажанням Лісабону припинити колоніальну війну ${ }^{37}$. У цьому контексті характерними $є$ слова

\footnotetext{
32 Loff M. Op. cit.; Osuna O., Javier J. Op. cit. P. 222.

33 Osuna O., Javier J. Op. cit. P. 222.

34 Сорайва Ж.Э. Указ. раб. С. 103; Pimenta, J.R., Sarmento, J. \& Azevedo A.F. Op. cit. P. 227.

35 Сорайва Ж.Э. Указ. раб. С. 103; Полонский И. Указ. раб.

36 Внешняя политика СССР. Учеб. пособие / Попов В.И. и др. Москва: Политиздат, 1972. С. 130.

37 Астафьева Е. Указ. раб.; Гомеш Г. Указ. раб. С. 16; Кузнецов Г. Указ. раб.
} 
лідера ПАІГК Амілкара Кабрала: «Ми не принизимо значення африканської солідарності та солідарності інших антиколоніальних сил у світі, якщо відверто скажемо, що саме від Радянського Союзу ми отримуємо найбільшу допомогу в нашій боротьбі» 38 .

Зауважимо, що з початком колоніальних воєн через шкільні програми та підручники, навчальні програми Вищої колоніальної школи у Лісабоні, виставки, телебачення тощо ідеї лузотропікалізму стали частиною народної географічної уяви ${ }^{39}$. Так, як справжнього португальця ідентифікували уродженця Мозамбіку Еусебіу, який у 1962 р. допоміг лісабонській «Бенфіці» виграти Кубок європейських чемпіонів.

Колоніальна війна та міжнародні санкції погіршили економічне становище країни. Вже на початок 1970-х років Португалія опинилася у глибокій економічній кризі та стала найбіднішою країною в Європі. Це супроводжувалося зниженням рівня життя та масовою еміграцією. Опозиційні ідеї, насамперед лівого спрямування, охопили широкі верстви суспільства, особливо молодь. Різко зріс авторитет компартії. Найконцентрованіше невдоволення режимом проявилося серед молодших і середніх офіцерів, насамперед, на фронтах колоніальних воєн, особливо після прийняття 13 липня 1973 p. закону-декрету 353/73 про «мілісіануш». Ним кадрові військові нижчої та середньої ланки фактично дискримінувалися на користь осіб, переважно студентів цивільних вишів, які отримували офіцерське звання за спрощеною процедурою. 9 вересня 1973 р. на зібранні біля міста Евора вони створили організацію «Рух капітанів», яка перебувала під сильним впливом компартії. Спочатку ії метою було скасування зазначеного закону-декрету. Але параліч економіки країни через нафтове ембарго арабських країн 1973-1974 рр. призвів до висунення 1 грудня революційної вимоги - повалення існуючого режиму шляхом військового перевороту ${ }^{40}$.

Меш ніж за півроку - 25 квітня 1974 р. - мети було досягнуто. Вся влада перейшла до Руху збройних сил і Ради національного порятунку. Переворот підтримали широкі верстви населення і він переріс у демократичну «Революцію гвоздик»41. Зазначимо, що спецслужби Португалії та розвідки провідних країн світу, зокрема США та СРСР, прогавили підготовку переворотуㄹ․

Два наступні роки Португалія балансувала між загрозою комуністичного перевороту та реставрації салазаризму. Шальку терезів як в один, так і в інший бік могло схилити втручання у португальські справи США та СРСР. На щастя португальців, обидві наддержави у цей час були зайняті налагодженням політики розрядки міжнародної напруженості та підготовкою загальноєвропейської Наради з безпеки та співробітництва і на пряме втручання піти не могли. Опосередкована ж підтримка виявилася більш ефективною у США. Можемо припустити, що використовуючи свої давні позиції серед старших офіцерів, Вашингтон сприяв перемозі в Португалії центристських сил, які згуртувалися довкола соціалістичної партії на чолі з Маріу Суаришем. Зазначимо, що за всієї різниці поглядів різних політичних сил Португалії, в одному вони були єдиними - у необхідності ліквідації колоніальної імперії. Впродовж 1974-1975 рр. було укладено угоди про незалежність Анголи, Гвінеї-Бісау, Островів Зеленого Мису (Кабо-Верде), Сан-Томе і Принсіпі ${ }^{43}$.

\footnotetext{
38 Внешняя политика СССР... С. 130.

39 Pimenta, J.R., Sarmento, J. \& Azevedo A.F. Op. cit. P. 226.

40 Куширець К.О. Вказ. пр. С. 116-117; Osuna O., Javier J. Op. cit. P. 225.

${ }^{41}$ Куширець К.О. Вказ. пр. С. 117; Aitor Hernández-Morales. Op. cit. P. 419-430.

42 Куширець К.О. Вказ. пр. С. 117.

43 Сорайва Ж.Э. Указ. раб. С. 104-104.
} 
Отже, аналіз розвитку португальської колоніальної імперії впродовж ХХ ст. неспростовно доводить, що попри різні внутрішньополітичні процеси у країні, вирішальне значення для ії існування мала сприятлива міжнародна ситуація. Зміна ж вектору міжнародних відносин на боротьбу з колоніалізмом і розрядки міжнародної напруженості призвела не лише до втрати Португалією міжнародної підтримки, а й до встановлення у країні демократичного режиму та надання колишнім колоніям незалежності.

\section{REFERENCES}

Aitor, Hernández-Morales (2018, 25 Abr.). Vasco Lourenço: «España le debe la democracia a la Revolución de los Claveles» [«Spain owes democracy to the Carnation Revolution»]. El mundo [in Spanish].

Astafeva, E. (2017, 13 Марта). Revoliutsiia gvozdik [Carnation Revolution]. Retrieved from: https://diletant.media/articles/34661719/ [in Russian].

Gilermo, G. (2004). Aprelskaia revoliutsiia $1974 \mathrm{~g}$. i demokraticheskie preobrazovaniia $v$ Portugalii (1974-1976 gg.). [The April Revolution of 1974 and the democratic transformation in Portugal (1974-1976)]. (Extended abstract of Candidate's thesis). Moskva [in Russian].

Gomesh, G. (2004). Aprelskaia revoliutsiia 1974 g. i demokraticheskie preobrazovaniia $v$ Portugalii 1974-1976gg. [The April Revolution of 1974 and the Democratic Transformation in Portugal 1974-1976]. (Extended abstract of Candidate's thesis). Moskva [in Russian]

Kuznetsov, G. (2016, 26 April). Konets velikoi imperii: kak «revoliutsiia gvozdik» razrushila Bolshuiu Portugaliiu [The end of the great empire: how the "carnation revolution» destroyed Greater Portugal]. Retrieved from: https://um.plus/2016/04/26/konec-velikojimperii-kak-revoljucija-gvozdik-razrushila-bolshuju-portugaliju/ [in Russian].

Kushyrets, K.O. (2017). Pidhotovka «Rukhom kapitaniv» revoliutsii hvozdyk. [Preparation of the Carnation Revolution by «Portuguese Armed Forces Captains»]. Gileya: naukovyi visnyk, 125 (10), 116-119 [in Ukrainian].

Loff, M. (2014). Dictatorship and revolution: Socio-political reconstructions of collective memory in post-authoritarian Portugal. Culture and History Digital Journal, 3 (2), online. Retrieved from: http://cultureandhistory.revistas.csic.es/index.php/cultureandhistory/article/view/56/2 13

Osuna, 0. \& Javier, J. (2014). The deep roots of the Carnation Revolution: 150 years of military interventionism in Portugal. Portuguese Journal of Social Science, 13 (2), 215-231. DOI: https://doi.org/10.1386/pjss.13.2.215_1

Pimenta, J.R., Sarmento, J. \& Azevedo A.F. (2011). Lusotropicalism: Tropical geography under dictatorship, 1926-1974. Singapore Journal of Tropical Geography, 32 (2), 220-235. DOI: https://doi.org/10.1111/j.1467-9493.2011.00430.x

Pires de Almeida, M.A. (2017). The revolution in local government: mayors in Portugal before and after 1974. Continuity and Change,32(2), 253-282. DOI: https://doi.org/10.1017/S0268416017000170

Polonskii, I. (2015). Novoe gosudarstvo professora Salazara [«New State» of the Professor Salazar]. Voennoe obozrenie. August 17. Retrieved from: https://topwar.ru/80608-novoegosudarstvo-professora-salazara.html [in Russian].

Popov V.I., etc (Ed.) (1972). Vneshniaia politika SSSR [The Foreign policy of the USSR]. Moskva: Politizdat [in Russian].

Potashinskaia, N.N. (2014). Tserkov Portugalii i «revoliutsiia gvozdik» [The Church of Portugal and Carnation Revolution]. Bereginia 777. Sova, 1, 153-167. Retrieved from: http://www.isras.ru/files/File/publ/Potashinskaya_Bereginya_2014_pdf [in Russian]. 
Pytlovana, L.Yu. (2015). Anhlo-nimetski superechnosti na afrykanskomu kontynenti na zlami XIX - XX st. ta yikh rol u narostanni kryzy systemy mizhnarodnykh vidnosyn naperedodni pershoi svitovoi viiny [English-German contradictions on the African continent at the turn of the XIX and XX centuries and their role in the growing crisis of the international relations system on the eve of the First World War]. In Narody svitu i Velyka viina 19141918 rr. Materialy Vseukrainskoi naukovoi konferentsii 3-4 kvitnia 2015 r. (pp. 19-25). Vinnytsia: TOV «Nilan-LTD» [in Ukrainian].

Raikhel, Yu. (2010). Profesor-dyktator. Pravlinnia Salazara tryvalo 40 rokiv. [ProfessorDictator. Salazar's governing lasted for 40 years]. Den. September 17. Retrieved from: https://day.kyiv.ua/uk/article/svitovi-diskusiyi/profesor-diktator. [in Ukrainian]

Soraiva, Zh.E. (2007). Istoriia Portugalii [The history of Portugal]. Moskva: «Ves mir» [in Russian].

Troian, S.S. (2011). Kolonialna polityka kaizerivskoi Nimechchyny u formati borotby za «mistse pid sontsem» (1896-1900 roku) [Colonial policy of Kaiser Germany in the format of the war for "place in the sun»(1896-1900). Istorychna pamiat, 1 (25), 94-109 [in Ukrainian].

Varela, R. (2012). «One, two, three MFA»: the rise and fall of Portugal\&apos;s Armed Forces Movement (MFA). Revista Brasileira de História, 32 (63), 407-430. DOI: http://dx.doi.org/10.1590/S0102-01882012000100019

Vale de Almeida, M. (2008). Portugal's Colonial Complex: From Colonial Lusotropicalism to Postcolonial Lusophony. Retrieved from: http://miguelvaledealmeida.net/wpcontent/uploads/2008/05/portugals-colonial-complex.pdf

\section{Mykola Oliynyk}

(Khmelnytskyi National University, Khmelnytskyi, Ukraine)

ORCID: https://orcid.org/0000-0002-3440-4965

\section{The Impact of International Relations on the Development and Collapse of the Last Colonial Empire in Europe}

The paper shows that at the beginning of the $20^{\text {th }}$ century the Portuguese colonial empire was actually a satellite of Britain. As a result of the 1910 revolution, the first republic was established. During the 16 years of its existence, 9 presidents, 44 prime ministers and 3 dictators changed, there were 25 uprisings, etc. The disorder contributed to the establishment of a military dictatorship in 1926. The military invited professor A. Salazar to overcome the crisis. He carried out successful reforms and founded the «New State» with an authoritarian regime. It was based on the ideology of corporatism and lusotropicalism.

The UK-oriented foreign policy provided a comfortable international position for the country during the interwar period, neutrality during the Second World War and cooperation with the anti-Hitler coalition made it possible to preserve colonies and become a founding member of NATO.

The disagreement with decolonization and the beginning of the colonial wars in 1961 led to the international isolation of Portugal, a deep economic crisis, and finally to a military coup on April 25, 1974, which turned into democratic «Carnation Revolution», establishing of democracy in the country and giving independence to the former colonies.

Keywords: salazarism, «Carnation Revolution», decolonization, democracy 